\title{
BECOMING LIKE CHILDREN OF GOD WHILE RAISING THEM: SEEKING HARMONY IN A POST-CHRISTIAN SOCIETY
}

\author{
Corinna Delkeskamp-Hayes*
}

\begin{abstract}
Should Christians seek harmony with their secular environment? Education presents a test case: Children must learn to function in a postChristian life-world, while also rooting themselves in the Church. This essay examines the groundwork provided in the Christian home: Mothers are called to raise children who will remain in the faith. They are also placed under Christ's enjoinder that all should become like children. Such a double task, so it is argued, imposes on mothers an 'ecclesial' self-understanding. The liberal, individualist mainstream in Europe opposes such a communal vision. It encourages catering to a robustly non-Christ-oriented child in oneself. Idolizing fallen nature, that mainstream subjects religious education to a hermeneutic of suspicion. Such a cultural setting recalls would-be children of God to the need of combining the guilelessness of doves with the shrewdness of serpents. Christian mothers need to develop strategies for defending their own struggles and for protecting their educational goals and methods. The Church can support such holy work by avoiding to either draft or tempt mothers into employment. She must present her public teaching in ways that provide helpful guidance while not provoking secular worries. In either case, the indispensable pursuit of harmony with those outside the Church must be carefully circumscribed in order not to compromise the integrity of a Christian education.
\end{abstract}

Keywords: Education, young people's liturgical life, the internal child, familyversus wage-work, Christian mothers, children's rights, discipline.

* Editor, Christian Bioethics-Non ecumenical Studies in Medical Morality, International Studies in Philosophy and Medicine. 


\section{Introduction}

Celebrating the beginning school year 2015-2016 with a message on Cooperation between Family, School and Church in the Field of Education, His Beatitude Daniel, Patriarch of the Romanian Orthodox Church ${ }^{1}$ set the stage for this conference's focus on young people in Church and society. Invoking St. John Chrysostom for the need to supplement academic learning by formation of the soul's virtue, the Patriarch highlights the saint's emphasis on discipline ... from the first. The saint himself ${ }^{2}$, of course, also insists on the need to separate children from the evil influence of their surrounding society (right down to regulating which slaves to involve in child care). It is surprising, therefore, to find Patriarch linking spiritual formation with the attainment of beauty in children's relation with the fellow human beings, with the society. The goal of allowing children to become citizens of the heavenly fatherland thus becomes merged with the goal of a harmonious life in their families and in the society.

This contrast between Patriarch and saint becomes even more striking, given the different social settings. Chrysostom addressed a Christian empire. While pagan traditions still remained, the ruling ethos, by imperial authority, affirmed Christian norms. The Patriarch, by contrast, addresses a society whose laws and public policies conform to the European Union's secular ethos of liberal individualism. While the saint saw a need for separation only in view of residual superstition, idolatry, and the moral decay that comes with un-redeemed fallen humanity, Christian educators today confront an educational ideology that affirms children's self-creative autonomy, inviting government and administrative interference. The

\footnotetext{
1 Cf. http://patriarhia.ro/cooperation-between-family-school-and-church-inthe-field-of-education-8208-en.html

${ }^{2}$ An address on vainglory and the right way for parents to bring up their children (transl. M.L.W. Laistner), Ithaka, NY, Cornell University Press, 1951, p. 85-122.
} 
quest for a harmonious life connecting such a society with Christian families is thus surprising.

Consider the discipline St. John enjoins: He sees the infant as wax in the father's hand, a parent's sculpture (op. cit. \#22). He welcomes a trembling and fearful attitude (\#20) that allows its character to be molded (\#21) by the parent ruling like a king over its soul (\#23, \#67, \#71). He recommends shortening the son's sleep for the sake of prayer, curbing any effeminate or foolish thoughts, imposing laws that inspire fear (\#24) because they will be enforced, (if needed) with blows, the rod (even though not constantly! \#30), and threats of the tawse. He endorses shielding the son from anything pernicious and corrupt (\#36), including frivolous tales (\#38). He endorses letting the fear of God shake his soul (\#40, \#85ff), threats of hell (\#52, \#76), keeping all women away (except the very old, \#53, $\# 79$, and the mother, \#62), even instilling a resolute spirit against womankind (\#62). He prohibits theatre visits (\#56), recommends extensive supervision of all outings, bribes in view of a good, prearranged marriage (\#61), humiliation as training for self-control (\#68), and instilling contempt in view of those who cherish different values $(\# 79)^{3}$. Obviously, a contemporary state accredited youth protection agency would find ample reasons to rescue a child from such a program: UNO's Declaration of the rights of the Child (in force since 1990), after all, recognizes freedom of expression,

\footnotetext{
${ }^{3}$ Nor is this an unusual account in Orthodox literature. See e.g. St. Theophan the Recluse, The path to salvation (transl. S. Rose), Platina, Ca., St. Herman of Alaska Brotherhood, 1998', as re-affirmed by contemporary priests like Ilja Schugaljew, Kindererziehung in der christlichen orthodoxen Familie (transl. K. Savinkin), Straelen, Ed. Hagia Sophia, 2009.

4 Office of the United Nations' High Commissioner on Human Rights, Convention on the Rights of the Child, 1989, http://www.ohchr.org/Documents/ProfessionalInterest/crc.pdf. On German cases in which a slap in the face by parents led to criminal action see: Daniela Agricola, Kinderschutz bei häuslicher Gewalt, Frankfurt: Diploma thesis, 2005, p. 24.
} 
seeking, receiving, and imparting information and ideas of all kinds, regardless of frontiers, either orally, in writing or in print, in the form of art, or through any other media of the child's choice (Art. 13 - 1), freedom of thought, conscience and religion (Art. $14-1$ ), freedom of association and to freedom of peaceful assembly (Art. 15 -1), protection against arbitrary or unlawful interference with his or her privacy, ... correspondence, ... unlawful attacks on his or her honor (Art. 16 - 1), access to information and material from a diversity of national and international sources (Art. 17), protection against all forms of physical or mental violence, injury or abuse (Art. $19-1)$, and the ability to participate freely in cultural life and the arts (Art. 31). The obvious love and responsible care inspiring the saint's recommendations would constitute no extenuating circumstance in a setting in which the child's best interest is assessed in robustly this-worldly terms.

The Patriarch's message surely also endorses the traditional Christian ideal. He envisages a Church that meets the needs of society as spiritual guide and light in the face of society's problems. Yet his hope for harmony recalls the way in which Christians in Western Europe have adjusted their own offer of guidance and light to what the secular society perceives as its needs and problems. There, the resulting harmony compromised the Christian message. It caused the loss of worshipers, merging of parishes, abandonment, profanation and destruction of church buildings. How, then, must an education toward citizenship in the heavenly fatherland be conceived in order for Orthodoxy to escape that fate?

The demise of Western Christianity cannot be attributed to modernity: Orthodox Jews in New York illustrates maintain their traditional faithfulness within modernity and its market economy. Christian demise comes from inside the faith. A recent study about young Roman Catholics in the United States ${ }^{5}$ explains their loss of Catholic identity, ever since the 1970s: Upward mobility through

${ }^{5}$ Christian Smith et al., Young Catholic America, New York, Oxford University Press, 2014. 
higher education imposed a geographic mobility that destroyed traditional family and neighborhood networks. Once part of the economic mainstream, young Catholics adopted the moral and political views of their new peers, even against official Catholic teaching. Vatican II, similarly eager to secure common ground with the secular moral mainstream, brought spiritual disorientation, dramatically reducing clerics, monastics, and teachers. With weakening religious education, parents became ever less able to pass on their faith. Each reduction in parental church attendance weakened the parental role model. The economic and intellectual quest for harmony with a secularized life-world brought substantial losses of faith.

This conference asks how young people can learn to support themselves in society while maintaining as primary goal their heavenly fatherland. Parents are the primary resource for such education. St. John Chrysostom's address, quoted above, focuses on fathers and sons. Yet today, his emphasis on very early formation challenges especially mothers ${ }^{6}$. Moreover, it is women's salvation which the Apostle renders contingent on their raising children who will stay in the faith (1. Tim. 2:15) ${ }^{7}$.

\section{Tensions between being a role model and acting it out}

What does it take to raise children in the faith? The study on US Catholic youth's loss of faith quoted above highlights parents' (crucial) impact through the example set (by regular mass attendance) and instruction about religious beliefs and values. Orthodoxy, on the other hand, focuses primarily on worship, and thus on the discipline which can enable children to enjoy long church services on Sundays and feasts. Only experienced joy, after all, will keep them coming, once parents' wishes are no longer imposed.

${ }^{6}$ St. Nectarios of Pentapolis, Mothers and the upbringing of children (transl. Th. Carroll), 2014. www.chrysostompress.org.

${ }^{7}$ As nuns, of course, they raise spiritual children. 
Catholics conceptually separate mass attendance from religious instruction. For Orthodox Christians, the faith is not primarily taught discursively: it is absorbed through liturgical prayer. The act of worshiping itself, moreover, provides training in the selfoffering of obedience. Such glorification is at the core of the faith as lived. The required discipline in Church challenges parents with seemingly contrary goals.

- They must offer an inspiring role model, and this seems to encourage a focus on their own prayer. Yet their children, left to themselves, may become bored, unhappy, unruly, even destructive.

- Therefore, parents must act the parent, and this seems to encourage entertaining the children in Church or outside, or even limiting their attendance to the event of Euraristic communion. The alternative of threats and punishments, while enforcing outward conformity, fail to teach the gospel of love the service was to celebrate ${ }^{8}$.

Even more: When Christ enjoins His disciples not to keep the children away, but to allow their access to Him, He charges today's mothers with the task of facilitating such access all through (at least) two and a half hours of standing in prayerful attention. At the same time, He presents those children themselves as universal role models. This complex task is aggravated by the ruling Zeitgeist. Its distortions affect both how mothers perceive the child-role they are to adopt (a), and their task of not hindering their children's access to Christ (b).

${ }^{8}$ Cf. Presbytera Juliana Cownie, Young children in the Orthodox Church, Etna, Ca., Center for traditionalist Orthodox Studies, 1996. 


\section{a) The role model of becoming like a child}

Christ's injunction that His followers must become like children (cf. Mt. 18:3) conveys a warning against the obsession with rank and authority, which their previous discussion about primacy had evinced ${ }^{9}$. Similar prejudices about important and less important people had already inspired the disciples' turn against mothers trying to elbow their children through the crowd (Mt. 13:14). Christ here presents Himself as one Whose love overrules, and discourages concern with, social norms, wherever these impede access to that love. His welcome of children (and enjoinder to welcome them) recalls similar warnings against a pious elite daring to disparage Christ's closeness to sinners. When criticized by self-righteous Pharisaeans about dining with the publican (Lk. 19:7) and about suffering a sinner's anointing His feet (Lk. 7:39), Christ presents His mission as therapeutic: He came to those who are (ready to recognize themselves as) sick, rather than to those who (claim to be) righteous, and therefore see no need for salvation (Mt. 9:12). His disparagement of what is today referred to as 'judgmentalism' also informs the way he saves an adulteress from stoning (Jn. 8:7), and His contrasting the publican with the Pharisee (Lk. 18:14). Seen in this wider context, the injunction to become like children prescribes a poverty of the spirit (cf Mt. 5:3) which is to remove all external as well as internal impediments (or 'defenses', as we would say today) against an unprejudiced and implicitly trusting openness to the kingdom of God (Mk. 10:15).

In a post-Christian culture, Christ's unconcern about social hierarchies was mis-translated into an exclusive focus on the individual, and on the internality of his religious or moral attitude: The body is no longer recognized as temple of the Holy Spirit, and personal spirituality is separated from communal worship. The incarnate character of a properly unselfish, other-regarding ascetical

${ }^{9}$ See St. John Chrysostom, Homilies on the Gospel of Saint Matthew (transl. G. Prevost, rev. M.B. Riddle), in: P. Schaff (ed.), Nicene and Post-Nicene Fathers, 1st series, vol.10, Peabody, Mass: Hendrickson Publishers, $1995^{2}$, p. $360 \mathrm{ff}$. 
discipline is no longer understood ${ }^{10}$. Child-friendly worshiping thus was identified with welcoming childish noise and distraction, all of which hinder, rather than promote, access to Christ, and do so for both children and grownup worshippers. Christ's injunction against judgmentalism was mis-translated into an attitude of who am I to judge? Here knowledge about the practically lived obedience owed the Divine Word, and about the sins which separate man from God, is confused with the presumption implied in judging sinners (as though one were God). The moral orientation available through liturgical worship thus loses its canonical salience, and its impact on daily life. The poverty of spirit commended in the benedictions, finally, was mistaken for reticence against confessing Christ as the Truth.

Such a (non-)culture encourages grownups to interpret as alienating the discipline they were subjected to in their own family, professional training, and social adjustment ${ }^{11}$. It encourages recovering the child in themselves, as the source of, or at least heuristic for, authentic selfhood ${ }^{12}$. That child's alertness to, and ability to demand fulfillment of, its wishes and needs is to redeem grownups from the imprisonment of social conditioning. Seen through such a distortive cultural lens, Christ's enjoinder that His followers should become like children encourages misconstruing mothers' educational task as one of allowing children to be and remain the children they already are, entitled to pursue what feels right and need-satisfying for them at any moment. During liturgy, this would justify mothers to pursue their own pious thing while

${ }^{10}$ See e.g. Willy Weber, Entdecke das Kind in dir - und werde Erwachsen, Holzgerlingen, SCM Hänssler, 2013.

${ }^{11}$ See e.g. Ekkehard von Braunmühl, Zeit für Kinder, Frankfurt, Fischer 1978, p. $20 \mathrm{f}$.

12 Most influential was here Eric Berne, Transactional Analysis in Psychotherapy, New York, Grove Press, Inc., 1961. 
abandoning their un-inhibited children to fellow-parishioners' patient forbearance.

Of course, the children Christ recommended as role models were those who, born of God, believe in the name of Christ (Jn. 1:12, cf. also Lk. 18:17). The unconcern about social status, which such belief is to inspire, recalls the unconcern about his worldly reputation, which drove the curious publican up the sycamore-tree. Similar unconcern about social norms framed the repentant sinner's wasting expensive Myrrh on Christ's feet. True children of God set their priorities on Christ, rather than getting caught up in the distraction of gain, work, or pleasure, like the guests who refused the Lord's banquet (Mt. 22:5).

Still, none of this is sufficient for solving the paradox involved in being like a child while raising them: As long as mothers conceive of their own vocation to be like a child that feels drawn to Christ in the culturally distorted terms of satisfying their own spiritual need, it remains unclear how they could at the same time help their children develop such a need. The difference between a merely selfish absorption in worship (i.e. a still self-distracted childishness) and a proper child-like focus requires a more detailed account of such commended child-like-ness.

\section{b) Raising role model children}

In his sermon on Mathew 18, St. Nikolai Velimirović ${ }^{13}$ highlights children's willing obedience, as based on their unquestioning faith in the good judgment undergirding parents' wishes. The optimism in the Saint's vision of children reflects his own experience with a still functioning Christian culture in Serbia's pre- and post-first-World War rural villages. Today, neither willing obedience nor unquestioning faith in parents' decisions are

${ }^{13}$ The Prologue from Ochrid, (transl. Mother Maria), I, Birmingham, Lazarica Press, 1985, p. 114f. 
encouraged, or even commended any more by the ruling culture. ${ }^{14}$ Instead, the Enlightenment's idolization of a stipulated original state of nature ${ }^{15}$ is taken to authorize children's spontaneous demands and pursuits as heuristic for the goodness inherent in their native authenticity. Humans' fallen state is here disregarded. Human flourishing is conceived in this-worldly terms exclusively, leaving no place for a Divine vocation ${ }^{16}$.

This teaching has also affected Western Christians seeking normative harmony with their secular environment: A predominantly Protestant construction of childhood in Christ takes humans' sinful state to be simply 'rescinded' by Christ's work of salvation ${ }^{17}$. The Christian life thus reduces to a grateful 'acceptance' of the grace thus bestowed, imposing only the firm commitment to fulfill what is morally imposed by the Divine commands. Subjected to the Enlightenment's eschatological vision of human progress, of course, those commands are adjusted to the secular norms of our time. Parental authority, as a training for recognized Divine authority, is therefore no longer affirmed among Christians in the West ${ }^{18}$.

${ }^{14}$ For a classic, see e.g. Paul \& Jean Ritter, Freie Kindererziehung in der Familie (transl. M. Dvořák, G. Stöhr), Hamburg, Rowohlt, 1972, p. 136f. The threats and promises through which St. John Chrysostom encourages parents to emulate the Divine education appear as black pedagogy (Richard B. Lyman, Barbarism and religion, in: L. deMause (ed.), The history of childhood, New York, Harper Torchbooks, 1975, p. 75-101, p.87).

${ }^{15}$ Cf. Ritter \& Ritter, op.cit., pp. 92, 193f, 206ff, 223, 248f.

${ }^{16}$ See e.g. Lloyd DeMause, The evolution of childhood, in L. deMause (ed.), The history of childhood, op. cit., p. 1-74, pp. 52f, or Ritter \& Ritter, ( op.cit. p. 189). Even psychoanalysts who, unlike the Ritters (op. cit., p. $173 \mathrm{ff}$ ) do not fall for Wilhelm Reich's pseudo-physicalism of love as energy, fail to understand the Divinely personal character of true love, thus ultimately reducing love to mutual utility, cf. eg. Wilhelm Schmid, Mit sich selbst befreundet sein, Frankfurt, Suhrkamp, 2004, p. 18f, 402 ).

${ }^{17}$ Christ Himself thus becomes the model anti-pedagogue because He accepted people for what they are (Braunmühl, op.cit.) 42.

18 See Mark J. Cherry, Familial authority and Christian bioethics, Christian Bioethics 2011, 17, p. 185-205, p. 186f. 
With man's Divine calling reduced to a guaranteed easyaccess 'justification', the challenge involved in man's synergetic cooperation with the Divine offer of deifying grace loses all meaning. The wisdom and will of Christian parents, even if marred by their own fallenness, is no longer understood as a resource for holiness: The head start which an early ascetical training can offer children in their struggle to control their self-will, and in their loving obedience to the God Who invites and rewards such struggle, have become inconceivable.

Against such theological distortions, Christian parents must cultivate their mental resistance. They must translate Christ's order not to keep the children away into the order to empower these children for the war they themselves will have to wage against the passions seeking to keep them from Christ. While imposing such disciplinary empowerment, parents must align their 'wisdom and will' with their own life 'as Church.' In this way, their educational program can be recognized by the children as implementing a not merely human, and questionable, but Divine rule. Parents' exercise of authority thus bears witness to their own, willingly child-like obedience and unquestioning faithfulness to God, or to the Divine wisdom of proper child-likeness, into which the children are invited ${ }^{19}$.

\section{c) An ecclesial resolution}

The project of framing one's educational authority in terms of a Divine obedience, and of enabling the children to profit from this, imposes a highly ascetical self-restraint on Christian parents. This holds in particular for mothers, and especially during worship. Re-directing children's fallen passions in a way that remains

19 Obviously, such aligning also accommodates parents' own exercise in humility: They must recognize their own weakness (and the exhaustion attending family care) by imposing rules of considerateness on their children. A godly parental rule is not incompatible with appeals to children's forebearance, when they see parents struggling with their own fallen nature. 
transparent to the love Christ remains a challenge. But at least the conceptual problem involved in that challenge can now be solved.

This problem reflects a distorted 'individualist' culture: In the West, individualism was affirmed against a presumed 'Medieval trust' in a divinely established, but outdated social order. Even Christians here invoke the Reformation. They endorse Luther's appeal to the authority of an individual conscience that claimed a biblical Truth of Christ outside of life as Church. With subsequent secularization, this focus on the individual engendered a liberal culture. Here humans count as autonomous, with the authority of their conscience downsized to an entitlement to choose their goals and aspirations. Even the Christian family is here conceived in terms of its individual members. Their respectively own, allegedly independent Christian vocation can thus conflict with family obligations in ways which Christ (Lk. 12:51-53) reserved for families not united in Christ. Only in such settings the focus on disciplining the children can repudiate mothers' attempt to become a child of Christ herself.

The Church, of course, recognizes humans as persons: Faced with the Divine creator's love, they are challenged to offer their free response. In rejecting or accepting their Divine vocation, humans find themselves either individualized to their lonely selves, or embraced by a Divine economy that encompasses their fellow humans, and in particular the Church. As thus embraced, Christian mothers no longer conceive of themselves (and their call to become children of God) apart from their calling to raise such children. When the Cherubic hymn invites all to leave their earthly distractions behind, a mother's struggle to keep her children in line no longer in principle differs from her struggle to keep her own heart, mind, and soul in line. The double vocation to be a child of God while raising them thus requires resisting the individualistic anthropology which is affirmed as canonical in the God-forsken West. Mothers only need to understand their very selves, as well as their families, in ecclesial terms. 
It is, of course, precisely such an ecclesially 'organic' account of the family, which the individualist liberalism of our secular environment denounces. Such families are seen as fertile ground for controlling, judging, psychologically manipulative parenting, and thus for violation of children's human rights to independence and self-determination. The following sections discuss ways in which Christian mothers can protect their Church-oriented educational work against interference from that environment, and ways in which the Church can support them.

\section{Resources for protecting the integrity of the household Church}

Not hindering children's access to Christ by offering them the ascetical training which in turn can foster children's sustained yearning for Christ is, obviously, a project that cannot be accomplished during Sunday liturgies. It is an all-weekday task, with its scheduled morning and evening prayers and blessing of meals. Attention in worship requires exercise, a developed skill in realizing how an icon looks back. Unlike walking and talking, such discipline does not grow (pretty much) by itself, and especially not in a hostile environment. Christian discipline requires constant, consistent, and inexorably watchful attention. It requires in particular time, discretion, and forgiveness.

\section{a) Time}

In order to nurture the love of God which can bear fruit during liturgy, it is not enough to make room in an otherwise busy schedule. In a setting of affluence, where pleasant distractions abound, a focus on God is hard to maintain. This holds especially for countries like Germany, where homeschooling is prohibited. With playmates and classmates discussing the fun things they are encouraged to pursue, Christian children will tolerate imposed ascetical efforts and constraints only if their compliance can be 
invited as an act of loving gratitude. In a life-world that encourages developing one's personal preferences, only children who desire to please will follow a mother's example without (too much) complaining. Such a desire must be nurtured through much loving care. The sons whom St. John Chrysostom wants Christian fathers to mold like wax will profit only if they are already established in strength and courage. These in turn grow from the emotional and spiritual security which a mother's reliable and attentive presence provides (and for daughters as well, of course) ${ }^{20}$. Outside of such preparation, and here the secular psychologists ${ }^{21}$ are right, the exacting demands recommended by the saint may easily destroy what they meant to nurture.

Mothers need time to be around ${ }^{22}$. Only a firm sense of cheerful belonging can also further that sense of family identity, which can resist peer pressure from outside the $\mathrm{Church}^{23}$. Only that same sustained presence and abundant love, moreover, can assure mothers, faced with their own failings, of the fullness of their selfoffering $^{24}$. An important antidote is thus secured against the temptation of allowing their own sentimental weakness and natural

${ }^{20}$ As St. Nectarios highlights, daughters may become the future mothers ( $o p$. cit., p. 8).

21 For one groundbreaking work about the importance of mother-child attachment see John Bowlby, Attachment and loss, 2, vols, London, Hogarth Press, 1969, 1973. Its reception was not friendly, because of the shadows his findings cast on mothers' seeking early employment (cf. vol. I, p. 344f, vol. II, p. $22 \mathrm{ff}, 322 \mathrm{f}, 369 \mathrm{ff})$

22 This need is recognized, already from a merely secular standpoint, in Susanne Mayer, Deutschland armes Kinderland, Frankfurt, Eichborn, 2002.

${ }^{23}$ Obviously, Church led family holidays can provide children with very helpful alternative peer enforcement of their family's religious profile.

${ }^{24}$ Obviously, the Pauline mindset that recognizes the mothers' obligation to love as an extension of Christ's command of love profoundly differs from a secular psychological mindset which, limited to the realm of immanence, refuses to see love as obligatory (cf. Braunmühl, op. cit., p.65). 
infatuation to interfere with their task of raising children in godly discipline.

Such maternal dedication does not sit well with the dominant ideology. Here motherhood is a biological accident that should not interfere with women's pursuit of intellectual or artistic selfrealization, economic independence, professional qualification, additional income and social recognition through employment outside the house. None of this, obviously, is compatible with the time-frame required for a Church-oriented education. Since it is, moreover, in fact still the wife who takes care of most household chores, even a half day of wage-work compromises mothers' opportunities for effective educational guidance.

In the post-Christian West, neither running one's household nor training one's own children is socially recognized as work. The implied opportunities for familial self-realization, managerial independence, psychological training, skillful saving and communal recognition among the like-minded notwithstanding, the absence of payment repudiates the social value of motherhood. Confronted with such prejudices, Christian families need to focus on their own antimainstream priorities. The harmony with society they can aspire to in this regard is modeled on St. Paul's advice about the need to keep separate (2. Cor. 6:17).

\section{b) Discretion}

A family's Christian discipline will be targeted by family members, friends, neighbors, caretakers and teachers in pre-school (if prescribed) or school (if obligatory or desired). The efforts and constraints that come with a training in asceticism must signal to outsiders the very opposite of pedagogic wisdom. Objections will be communicated through moral accusations, bureaucratic interventions, and sometimes even legal threats ${ }^{25}$.

${ }^{25}$ For an identification of parental education with a violation of children's rights see Braunmühl, op.,cit. p. 182f. Increasing tendencies to interfere with family authority in the name of children's best interests is well illustrated by 
In the face of such risks, Christian mothers will remember Christ's prediction about the need for both, the guileless-ness of doves and the craftiness of serpents (Mt. 10:16). They can foster affectionate friendships and support networks right across the abyss of deep spiritual disagreement. In engaging with their potential critics, they can devise strategies for cooperation, which are both unobjectionable by their own standards and welcome for the other side. Offering self-less practical help among friends and neighbors, supporting feasts, outings, and special events staged by the children's pre-schools and schools, welcoming the work of caretakers and teachers and complying with whatever rules will not compromise their mission can protect the integrity of the family's private space against unfriendly intervention. While such a life imposes the task of not betraying the faith, Christ's enjoinder that those who are exposed to persecution should go into hiding (Mt. 10:23) issues a warning: One must not take on more than one can endure.

Still, the harmony with society nurtured here reflects the Apostle Peter's advice that Christians should aspire to a (defensively cultivated) good reputation among those outside the Church (1. Pet. 2:12).

\section{c) Forgiveness}

Christian mothers, while engaged in such cautious distancekeeping and reputation-nurturing, must still take care not to compromise their own integrity as children of God. Their role model

Alexandra Retkowski, Barbara Schäuble, \& Werner Thole, Sorgende Arrangements im Kinderschutz, in idem (eds.) „Sorgende Arrangements, Wiesbaden, Springer, 2012, p. 9-15, p. 11, and in Ingo Bode, Steffen Eisentraut, \& Hannu Turba, Kindeswohlgefährdung als Systemfrage, in op.cit., p. 39- 49, p. 43. For a summary of the ways in which interference with families' religious education is generally accepted see Corinna DelkeskampHayes, Viaţa eucharistică şi martiriul creştin: Punerea sub semnul intrebării a etosului secular al Europei, in: M. Himcinschi, J. Nicolae (eds.), Eucharist and Martyrdom, Alba Iulia, Reǐntregirea Publishing House, 2014, p. 63-88, p. 65ff. 
will therefore in addition seek to emulate the children whom Saint Nikolai describes as ever ready to forgive (op. cit., p. 114).

In a post-Christian, often even anti-Christian environment, Christian parents must keep their children from being harmed by the pervasive presence of advertisements, printed and electronic media, religious syncretism and out right idolatry encouraged through government controlled child care and school materials in the name of non-discrimination and religious tolerance, and by the aggressive implementation of gender mainstreaming and sex education, which such institutions promote for the sake of emancipation and moral diversity. Living a Christian life in a society that denounces the pursuit of holiness as illusionary and alienating is to find oneself immersed in inescapable cultural warfare.

Yet Christian parents must avoid letting themselves be drawn into merely outward warfare, even if waged only in the privacy of their home or parish. The temptation, while fighting against those who oppose Christ. is to neglect the blessed fight against one's own (and one's children's) fallen nature. The role of a cultural warrior easily overshadows the mission of the spiritual warrior. Only a fine line separates those who hate their own sinful inclinations (disapproving of them in their children) from those who hate others for ratifying such inclinations as entitlements, for justifying their impact on (what they conceive as human flourishing), and for discounting the very meaning of sin. The challenge remains to oppose whatever impedes our Divine vocation without becoming distracted ourselves. Only repentance for one's own sins, and repentance about one's limited ability to help the children overcome theirs, brings spiritual gain. Only such gain can keep the children in the Church.

The aspiration to harmony with society here assumes a further meaning. Even while struggling to protect their children from and warn them against a misguided world, Christian parents must aspire to that inner harmony which comes as a Divine gift of peace. When the Apostle Jude (1:23) admonishes his parish to be merciful 
to those who cannot be called in, but to hate the very garment which their flesh has soiled, he offers guidance about how to recognize the image of God even in those who betray that image.

\section{The role of the Church}

Like a mother, the Church seeks to raise children of God, even if most of these have reached maturity and must adopt her discipline freely. Like a mother, the Church must witness to what she proclaims. One of the challenges this involves arises from her task of bringing to those outside the Gospel of the Divine love. This mission might well be taken to oblige her to seek some kind of antecedent harmony with those she is called to convert. And indeed, the Church welcomes, and prays for, political, social, and economic peace. Like Christian parents, she seeks to be at a godly peace with her nongodly environment without compromising the integrity of either her proclamation or her witness.

\section{a) Challenges to her proclamation}

In post-Christian Europe, the Church finds herself placed alongside other Christian bodies. These others frame their message in a way that is designed to avoid being classified as threat to social peace. The Church, concerned about avoiding the implied integrity loss, while yet not attracting active hostility, can develop her own strategies:

- In regard to existing laws and regulations, she can affirm her commitment to compliance, as long as this does not implicate her in sin. At the same time, she can proclaim her moral guidance, even where this implies identifying certain laws and regulations as either distracting or misguiding. 
- In regard to the dominant ethos of her secular environment, the Church can abstain from passing judgment about the salvational opportunities of non-Orthodox subscribers to that ethos. At the same time, she can disparage that ethos as distorted.

Applied to Christian education, this twofold double-strategy has important implications. One of these concerns the principle of equality between the sexes in European law and public policy. While not questioning the legal force of that principle, the Church can protect her survival in a hostile environment only if she denounces the implied feminism as distracting. She must highlight humans' sexually differentiated vocations, i.e. recall women to their salvation through motherhood. On this level, her efforts to establish harmony with her cultural environment can avoid deceiving Christian parents about their profoundly counter-cultural work ${ }^{26}$.

Another implication of her double strategy concerns the priority of social peace over issues of truth. This principle undergirds Europe's ethos of welcoming alternative (albeit peace-preserving!) visions of human flourishing in a way that recognizes these visions as in themselves legitimate. Such an ethos makes sense for an exclusively immanence-oriented culture. Here the Divine judgment is discounted as either unreal or else redundant, because of God's assumed undiscerning goodness. While not denying the theoretical possibility of wholesale Divine mercy, the Church can protect her survival in a hostile environment only if she condemns such carelessness as misguiding.

Clearly, outside of a lifeworld in which this earthly life is properly understood as a time of trial, or as opportunity to accept or reject the Divine offer of grace through Christ, a rightly oriented

\footnotetext{
${ }^{26}$ This is a formidable task, given the secular mainstream's preoccupation with the relationship between patriarchical family structures and (no, not unselfishly faithful care for one's dependents but) violence against women (cf. Agricola, op. cit., p. 73).
} 
Christian education cannot but appear ideological and sectarian. If this earthly life is all there is, human flourishing must be secured in the here and now. Children must then be enabled to pursue what they themselves, in their unlimited, and ever changing, diversity of tastes and preferences, may conceive at any given moment as happiness for themselves and their dear ones. Discipline and self-control will still have a place, to be sure. But its purpose envisages nothing beyond the self-mastery needed for securing long term satisfaction, and for safeguarding options for future choices. Within the framework of a Christian education, on the other hand, discipline and self-control are oriented towards the art of self-denial. Such education aims at enabling children to follow Christ by willingly taking up their cross, and learning what it means to love God first, and themselves precisely insofar as that primary love enjoins.

The vigorous resistance which post-Christian societies offer to such an educational program reflects understandable resentments. These concern cultural deformations which certain heterodox Christian teachings had inflicted on the West during the thousand years of non-Orthodox Christians' political and social predominance. Here the eschatological horizon of a Final Judgment had been instrumentalized for political purposes, both within heterodoxy's own clerical polities and within the Christian polities supported by their faiths: Teaching about the hell that awaited those who failed to comply with official religious and moral norms had indeed been used for moral and political intimidation. Teaching about the paradise that awaited those who accepted without protest their suppression and exploitation had indeed been used as cheap consolation. In the postChristian public discourse today, such distortions and misuses have motivated many, especially psychologists and pedagogical experts, to subject even the undistorted proclamation of man's eternal Divine vocation to a hermeneutic of suspicion.

For the Church and her public proclamation, all of this presents a further challenge: While preserving the integrity of her moral and spiritual Tradition, she must also protect her message 
against being mistaken for an instrument for familial, social and political suppression, and as an excuse for the failure to turn in charity to those who suffer during their earthly life. Especially this latter aspect presents a further burden for the witness the Church needs to offer, by living what she proclaims.

\section{b) Challenges to her witness}

The primary place, in which the Church attends to human suffering is, of course, her worship: The healing power of prayer and repentance transforms already this earthly life.

Inseparable from her liturgical life, the Church offers her works of philanthropy. She does so, to a large extent, through institutions in which she acts as employer. Should she employ mothers ${ }^{27}$ of young children? ${ }^{28}$ As the preceding sections have argued: In a setting without government support and with all societal forces acting against Christ, her own future depends to a large extent on mothers' willingness to pursue their Pauline vocation. This essay has also argued that, given today's adverse conditions, this task requires those mothers' sustained presence at home. Such presence is incompatible with out-of-the-house wage work.

27 The Church employs women not only in her social departments but in her administrative and secretarial offices, libraries, church shops, church bakeries and archives. All in all, by estimation of an employee of the Iasi Metropolitan center, the number of female Church employees in Romania may be around 1000. Even if this does not look impressive numerically, the engagement of mothers as wage workers signals unconcern about mothers' mission.

${ }^{28}$ It is, of course, a great mistake to limit the importance of a 'present' Christian mother to young children. Communication with teenage children is difficult. It is risky to hope for 'quality interaction' in the few hours between end of (wage- and house-) work and time for bed. Puberty renders children less reachable, and a sustained intimate relationship requires that one can seize the precious right moments. Even more, older children need different kinds of (discrete, to be sure!) supervision in order to stay clear of the more dangerous temptations inherent in today's youth culture. 
The challenge which this fact presents to the witness of the Church affects both, her worship and her philanthropy. The first concerns wives of priests. Where priests earn not enough of a salary to support their own families, they are left with two alternatives: They must either seek employment for themselves, thus compromising their pastoral work. Or else they must render the family dependent on additional income earned by their wives, thus compromising the latter's family work. To some extent, surely, the priest-father, or some other relative, may step in. But is this the rule? And what example does such a priestly family offer its parishioners? A hierarchy that offers priests a sufficient salary, or helps them generate income from their parishioners, powerfully signals her endorsement of mothers' vocation. A hierarchy that neglects such a signal, compromises her witness.

The second challenge concerns philanthropy. Clearly, the income a mother earns by employment in such works may be the only way to keep her family fed. If the alternative is starvation, a job offer is in itself philanthropic. The Church may even establish her own child care centers and day schools in order to contain the damage at home. Recent developmental psychology research, of course, has shown that the quality of institutional care, measured even just in terms of merely secular criteria, hinges on the quality and number of employees ${ }^{29}$. The required financial and leadership resources would present their own burden for the Church. Such an offer might therefore have to be limited to emergencies.

In all other cases, the Church can derive guidance from the Apostle Paul's discussion of widows on the list of the Church (1.

29 A recent German meta-study shows that opportunities for adequate interaction between caretakers and children, even outside of the special demands imposed by an Orthodox education, are limited by given ratios: For children under three a relationship of 1:3, for children over three and under five to 1:7 are recommended as threshold values (Susanne Viernickel \& Stefanie Schwarz, Schlüssel zu guter Bildung, Erziehung und Betreuung, Berlin: GEW Berlin, 2009, p. 15). 
Tim. 5:9). Such widows were authorized to offer the philanthropic service of their prayers and spiritual guidance, and thus to qualify for an assistance (1. Tim. 5:15) that remotely resembles today's salaries. Yet inclusion in that list depended on there being no families obligated to provide support, and no children or grandchildren to whose care the Apostle referred widows' primary religious duty (1. Tim. 5:4).

While the Church is called to witness to what she teaches by caring for those who suffer or are in need, her diaconic institutions must not be 'manned' in a way that belies her teaching about more important duties. In fact, her diaconic presence in society could revive that ancient order of widowhood. The way in which such an order could bring a Christian witness to a bioethics of care, especially care to the handicapped, the old, and the dying, has recently been developed in an issue of Christian Bioethics ${ }^{30}$. As these studies show, a powerful Christian witness is possible without tempting mothers away from raising their children in the faith.

\section{Conclusions}

This essay has examined the sense in which the Church, in her concern for the education of the young, can aspire to the harmony with regard to society, which the Romanian Patriarch's 2015 message to school children invoked. Taking up his reference to St. John Chrysostom's' treatise on early Christian formation, this essay has focused on the complex task such formation imposes on mothers, given their calling to become like a child of God while raising such children. Starting out with the hostility which Europe's predominantly post-Christian society evinces against any educational discipline that is not justified by professional, artistic, or athletic

\footnotetext{
${ }^{30}$ See especially H. Tristram Engelhardt, Jr., The bioethics of care, in: Christian Bioethics, 2005, 11, p. 1-10, M. Cathleen Kaveny, The order of widows, in: op. cit., p. 11-34, and Christina T. Partridge \& Jennifer Turiaso, Widows, women, and the bioethics of care, in: op. cit., p. 77-92).
} 
objectives, this essay has laid out various senses which such quest for harmony might legitimately adopt.

There is indeed little common ground between an educational vision that seeks to qualify children for citizenship in their heavenly fatherland and one that limits its concerns to earthly wellbeing. The Church in Europe today serves her heavenly mission in an immanence-obsessed environment, and so do her educators, especially Christian mothers. Warned by the self-destruction that has rewarded Western mainline Christians' attempt to secure their secular welcome by adjusting to that obsession, the Church can

- affirm (and prayerfully ask for) a harmony of external peace as condition for parents' ability to cultivate their own household Church,

- confess a harmony of legal compliance which creates space for such cultivation,

- affirm the harmony of a recognized common dependence on the Divine mercy in order to protect Orthodoxy's good reputation as non-judgmentalist and non-discriminating,

- pursue her harmony of charity with those in need without distracting mothers from their vocation,

- encourage Christian families to secure their own harmony of remaining separate from the distractions of their surroundings,

- advise Christian mothers to promote a harmony of social cooperation in order to shield their family privacy from unwelcome scrutiny,

- teach Christian parents to guard their harmony of inner peace during their exposure to cultural warfare.

In each case, harmony in view of a post-Christian environment is not simply confessed or invoked. Instead, it is reconfigured so as to protect the integrity of the Christian mission against the distractions and distortions affirmed by Europe's ruling 
ethos. Outside of a freely accepted suffering of confessorship, Christian educators here must take every care to avoid the threat of outside interference. Those who raise children of God, just like the children they raise, will have to integrate their dove-like guilelessness with the shrewdness of godly serpents. By carefully avoiding harmony with a disruptive social environment, they can still aspire to the many facets of harmony within that environment, which this essay has laid out.

\section{References}

1. Agricola, Daniela, Kinderschutz bei häuslicher Gewalt, Frankfurt: Diploma thesis, 2005.

2. Berne, Eric. Transactional Analysis in Psychotherapy, New York, Grove Press, Inc., 1961.

3. Bode, Ingo, Eisentraut, Steffen \& Turba, Hannu, Kindeswohlgefährdung als Systemfrage, in Alexandra Retkowski, Barbara Schäuble, \& Werner Thole (eds.) ,Sorgende Arrangements, Wiesbaden, Springer, 2012, p. 39- 49.

4. Bowlby, John, Attachment and loss, 2, vols, London, Hogarth Press, 1969, 1973.

5. Braunmühl, Ekkehard von, Zeit für Kinder, Frankfurt, Fischer 1978.

6. Cherry, Mark J., Familial authority and Christian bioethics, Christian Bioethics 2011, 17, p. 185-205.

7. Cownie, Juliana (Presbytera), Young children in the Orthodox Church, Etna, Ca., Center for traditionalist Orthodox Studies. 1996.

8. Delkeskamp-Hayes, Corinna, Viaţa eucharistică şi martiriul creştin: Punerea sub semnul ǐntrebării a etosului secular al Europei, in: M. Himcinschi, J. Nicolae (eds.), Eucharist and Martyrdom, Alba Iulia, Reǔntregirea, 2014, p. 63-88.

9. DeMause, Lloyd. The evolution of childhood, in: L. deMause (ed.), The history of childhood, New York, Harper Torchbooks, 1975, p. 1-74.

10. Engelhardt, H. Tristram Jr., The bioethics of care, Christian Bioethics, 2005, 11, p. 1-10,

11. (St.) John Chrysostom, An address on vainglory and the right way for parents to bring up their children (transl. M.L.W. Laistner), Ithaka, NY, Cornell University Press, 1951, p. 85-122.

12. (St.) John Chrysostom, Homilies on the Gospel of Saint Matthew (transl. G. Prevost, rev. M.B. Riddle), in: P. Schaff (ed.), Nicene and Post-Nicene Fathers, 1st series, vol. 10, Peabody, Mass: Hendrickson Publishers, $1995^{2}$. 
13. Kaveny, M. Cathleen, The order of widows, in: op. cit., p. 11-34.

14. Lyman, Richard B., Barbarism and religion, in: L. deMause (ed.), The history of childhood, in: op. cit., p. 75-101.

15. Mayer, Susanne, Deutschland armes Kinderland, Frankfurt, Eichborn, 2002.

16. (St.) Nikolai Velimirović, The Prologue from Ochrid, (transl. Mother Maria), I, Birmingham, Lazarica Press, 1985.

17. Partridge, Christina T. \& Turiaso, Jennifer, Widows, women, and the bioethics of care, in: op. cit., p. 77-92.

18. Retkowski, Alexandra, Schäuble, Barbara \& Thole, Werner, Sorgende Arrangements im Kinderschutz, in idem (eds.) „Sorgende Arrangements, Wiesbaden, Springer, 2012, p. 9-15.

19. Ritter, Paul \& Jean, Freie Kindererziehung in der Familie (transl. M. Dvořák, G. Stöhr), Hamburg, Rowohlt, 1972

20. Schmid, Wilhelm, Mit sich selbst befreundet sein, Frankfurt, Suhrkamp, 2004.

21. Schugaljew, Ilja (Priest), Kindererziehung in der christlichen orthodoxen Familie (transl. K. Savinkin), Straelen, Ed. Hagia Sophia, 2009 Schugaljew, Ilja, Priester, kindererziehung in der christlichen orthodoxen Familie, Ed. Hagia Sophia 2009.

22. Smith, Christian, et al., Young Catholic America, New York, Oxford University Press, 2014.

23. (St.) Theophan the Recluse, The path to salvation (transl. S. Rose), Platina, Ca., St. Herman of Alaska Brotherhood, $1998^{2}$.

24. Viernickel, Susanne \& Schwarz, Stefanie, Schlüssel zu guter Bildung, Erziehung und Betreuung, Berlin: GEW Berlin, 2009.

25. Weber, Willy, Entdecke das Kind in dir - und werde Erwachsen, Holzgerlingen, SCM Hänssler, 2013.

\section{Web-sources:}

1. (Patriarch) Daniel, Cooperation between family, school and Church in the field of education, 2015, http://patriarhia.ro/cooperation-between-family-schooland-church-in-the-field-of-education-8208-en.html (accessed 25 March 2016).

2. (St.) Nektarios of Pentapolis, Mothers and the upbringing of children (transl. Th. Carroll), 2014. www.chrysostompress.org (accessed 25 March, 2016).

Office of the United Nations' High Commissioner on Human Rights, Convention on the Rights of the Child, 1989,

3. http://www.ohchr.org/Documents/ProfessionalInterest/crc.pdf (accessed 24 March 2016). 